\title{
METABOLISM OF L-THYROXINE BY MITOCHONDRIA OF VARIOUS RAT TISSUES IN THE PRESENCE OF PYRIDOXAL PHOSPHATE AND $\alpha$-KETOGLUTARATE, DIPHOSPHOPYRIDINE NUCLEOTIDE OR FLAVIN MONONUCLEOTIDE
}

\author{
Kiyoshi Yamamoto, Shoojiro Shimizu and Ichiro Ishikawa* \\ Department of Physiology, Institute of Endocrinology, \\ Gunma University, Maebashi
}

The authors have been engaged in a series of in vitro studies on the deaminative degradation of L-thyroxine $\left(\mathrm{T}_{4}\right)$, and demonstrated the presence of the $\mathbf{T}_{4}$-transaminase employing rat kidney homogenate ${ }^{9)}$ and mitochondria ${ }^{11)}$, to which were added pyridoxal phosphate and some amino group acceptors as the enzyme cofactors. On the other hand, a DPN-linked enzyme was reported by Albright and his collaborators to metabolize $T_{4}{ }^{8)}$ and triiodothyronine $\left(T_{3}\right)^{1)}$. This enzyme was obtained in a soluble state from rat kidney mitochondria. Our recent work indicated that the DPN-linked enzyme is less active than the transaminase in deaminating $\mathrm{T}_{4}$, when kidney mitochondria are used as enzyme sources $^{11}$.

L-amino acid oxidase was regarded by many workers as the main enzyme to deaminate thyroid hormones. As far as the authors are aware, however, this has never been confirmed in experiments with mammalian tissues, although such indications were given by NAKANO et al. ${ }^{2}$, who have shown that L-amino acid oxidase derived from snake venom actively metabolizes $T_{4}$ and $T_{3}$.

The present investigation was undertaken in order to obtain informration concerning the distribution of these three enzymes among mitochondrial fractions of rat tissues. The results have shown that the transaminase and the DPN-linked enzyme are markedly active only in the kidney. Regarding L-amino acid oxidase, the attempt to detect the enzyme activity was not successful. However, during this study it was found that flavin mononucleotide (FMN), the coenzyme of $\mathrm{L}$-amino acid oxidase, enhances the deiodination of $\mathrm{T}_{4}$ by kidney or liver mitochondria; the distribution of this deiodinase being described below.

The results have been included in part in a paper read in the First Asia and Oceania Regional Congress of Endocrinology in Kyoto, Nov. 1, 1959.

Received for publication April 24, 1960.

*山本 清, 湆水正二郎, 石州一郎 


\section{MATERIALS AND METHODS}

Mitochondrial fractions, isolated from the kidney, liver, heart, femoral muscles and the whole brain of adult male Wistar rats, were used as enzyme sources. The isolation procedures, the method of preparation of radioactive $T_{4}$ and the analytical procedures of the reaction mixtures for the radioactive metabolites were essentially the same as described previously ${ }^{11)}$. The activity of the transaminase and DPN-linked enzyme was estimated on the basis of the conversion of $\mathrm{T}_{4}$ to $\mathrm{TA}_{4}$, and that of the FMN-linked deiodinase on the basis of the liberation of inorganic iodide from $\mathrm{T}_{4}$. In these experiments, $\alpha$-ketoglutarate was applied in a final concentration of $10^{-2} \mathrm{M}$ and coenzymes, pyridoxal phosphate, DPN and FMN, in $10^{+4} \mathrm{M}$ respectively. Pyridoxal phosphate was a gift from Dr. K. OoIKE, Wakamoto Drug Lab. The other three cofactors were obtained from commercial sources.

These experiments were carried out from September to November.

\section{RESULTS}

Table 1 is a summary of representative data obtained from one experiment, in which mitochondria derived from the same rat organs were employed. Table 1,

TABLE 1

Metabolites of $T_{4}$ Formed by Three Enzymes of Rat Tissue Mitochondria

\begin{tabular}{|c|c|c|c|c|c|c|c|c|}
\hline & \multirow{2}{*}{$\begin{array}{c}\text { Enzyme cofactors } \\
\text { added }\end{array}$} & \multirow[t]{2}{*}{ Tissues } & \multicolumn{5}{|c|}{$\begin{array}{l}\text { Percent distribution of } \\
\text { radioactivity among }\end{array}$} & \multirow[t]{2}{*}{$\mathrm{TA}_{4} / \mathrm{T}_{4}$} \\
\hline & & & $\mathrm{T}_{4}$ & $\mathrm{TA}_{4}$ & $\mathbf{I}^{-}$ & $\mathrm{O}$ & Residual & \\
\hline \multirow{6}{*}{ A } & \multirow{6}{*}{$\begin{array}{l}\text { Pyridoxal } \\
\text { phosphate, } \\
\alpha \text {-Ketoglutarate }\end{array}$} & Control* & 74 & 5 & 10 & 2 & 9 & 0.07 \\
\hline & & Kidney & 36 & 28 & 12 & 17 & 8 & 0.78 \\
\hline & & Liver & 60 & 14 & 9 & 7 & 10 & 0.23 \\
\hline & & Heart & 59 & 11 & 10 & 8 & 12 & 0.19 \\
\hline & & Skeletal muscle & 65 & 12 & 11 & 4 & 8 & 0.18 \\
\hline & & Brain & 63 & 10 & 9 & 5 & 13 & 0.16 \\
\hline \multirow{6}{*}{ B } & \multirow{6}{*}{ DPN } & Control* & 71 & 6 & 7 & 3 & 13 & 0.08 \\
\hline & & Kidney & 53 & 14 & 8 & 11 & 14 & 0.26 \\
\hline & & Liver & 62 & 10 & 9 & 7 & 12 & 0.16 \\
\hline & & Heart & 62 & 12 & 7 & 10 & 9 & 0.19 \\
\hline & & Skeletal muscle & 66 & 11 & 6 & 4 & 13 & 0.17 \\
\hline & & Brain & 61 & 11 & 9 & 5 & 14 & 0.18 \\
\hline \multirow{6}{*}{$\mathrm{C}$} & \multirow{6}{*}{ FMN } & Control* & 61 & 6 & 12 & 6 & 15 & - \\
\hline & & Kidney & 25 & 9 & 20 & 24 & 22 & - \\
\hline & & Liver & 25 & 6 & 26 & 26 & 17 & - \\
\hline & & Heart & 49 & 8 & 14 & 12 & 17 & - \\
\hline & & Skeletal muscle & 47 & 11 & 12 & 16 & 14 & - \\
\hline & & Brain & 52 & 10 & 12 & 11 & 15 & - \\
\hline
\end{tabular}

* $\mathrm{T}_{4}$ was incubated only with respective cofactors, without addition of tissue mitochondria. 
A and FIG. 1 show the distribution of $\mathrm{T}_{4}$-transaminase. The amount of $\mathrm{TA}_{4}$ formed and $\mathrm{T}_{4}$ consumed was the greatest in the case of kidney mitochondria. The ratio $\mathrm{TA}_{4} / \mathrm{T}_{4}$, which was calculated in order to show roughly the degree of deamination and was listed in Table 1, was also the greatest in this case. Liver mitochondria were much less active, though in a few of the other experiments was an activity comparable to that of kidney observed. The other tissues exhibited only a little activity in all experiments.

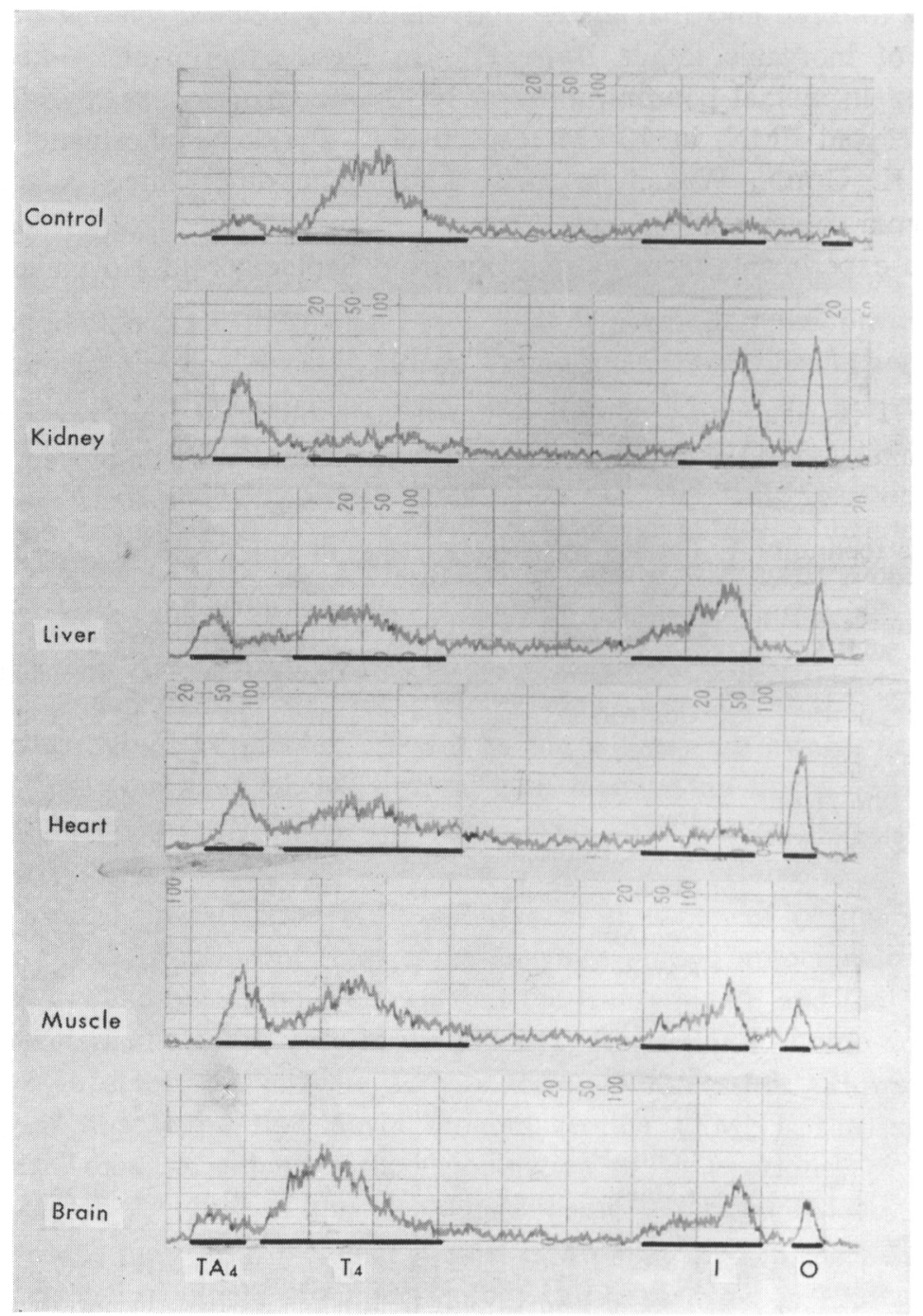

FIG. 1. Formation of $\mathrm{TA}_{4}$ from $\mathrm{T}_{4}$ by mitochondrial $\mathrm{T}_{4}$-transaminase of various rat tissues. $\mathrm{T}_{4}$ : L-thyroxine, $\mathrm{TA}_{4}$ : tetraiodothyroacetic acid, $\mathrm{I}^{-}$: inorganic iodide, $\mathrm{O}$ : origin. (Butanol: Acetic acid: $\mathrm{H}_{2} \mathrm{O}$ ). 
TABLE 2

Nitrogen Content of Mitochondria Isolated from $400 \mathrm{mg}$. of Rat Tissues

\begin{tabular}{lc}
\hline \multicolumn{1}{c}{ Tissues } & Nitrogen content $(\mathrm{mg})$ \\
Kidney & 0.499 \\
Liver & 0.647 \\
Heart & 0.252 \\
Skeletal muscle & 0.166 \\
Brain & 0.664
\end{tabular}

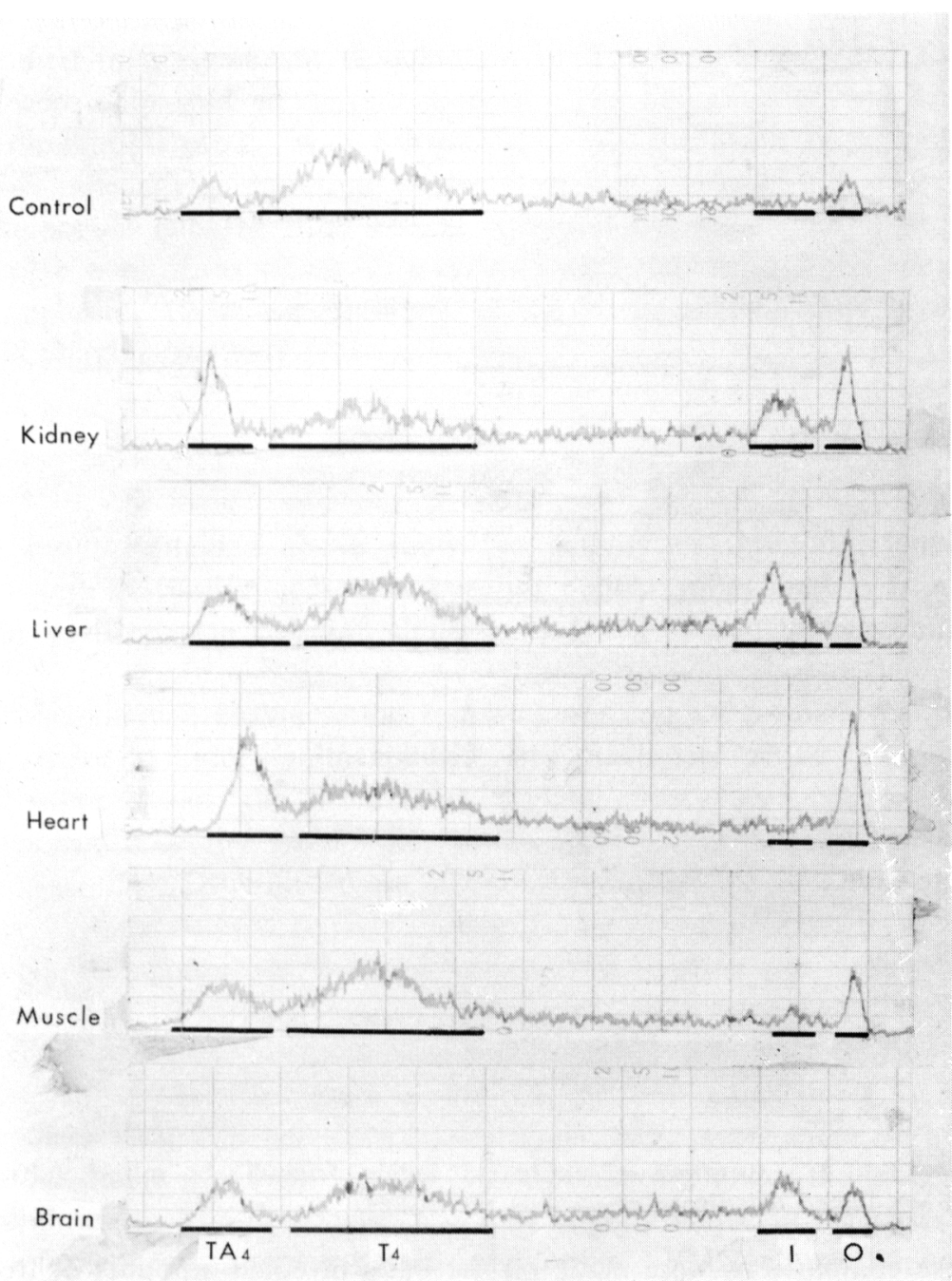

FIG. 2. Formation of $\mathrm{TA}_{4}$ from $\mathrm{T}_{4}$ by mitochondrial DPN-linked deaminase of various rat tissues. 


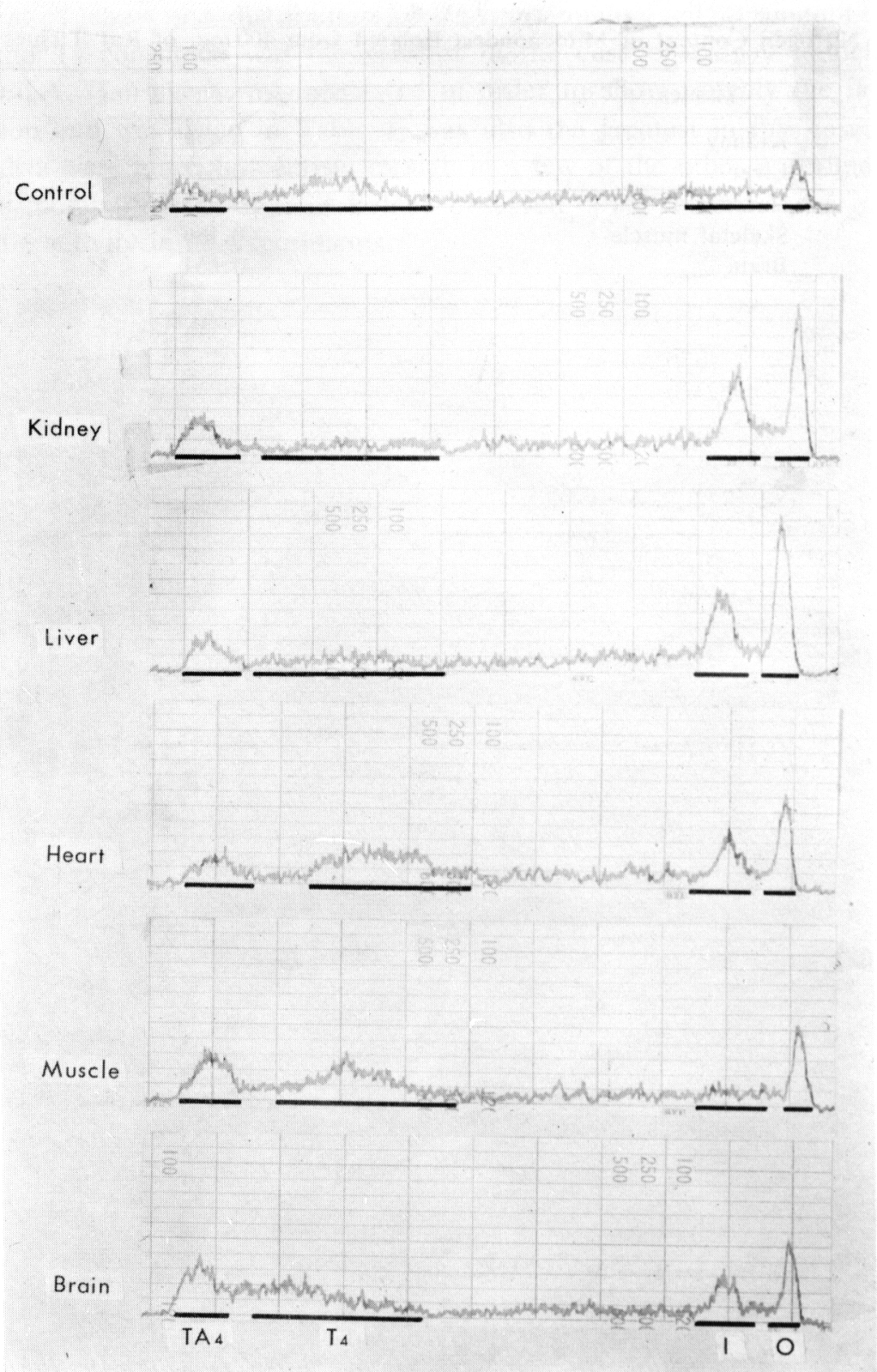

FIG. 3. Liberation of inorganic iodide from $\mathrm{T}_{4}$ by mitochondrial FMN-linked deiodinase of various rat tissues.

These comparisons were made on the basis of equal amounts of fresh tissue, i.e., $400 \mathrm{mg}$. of wet weight. Although the nitrogen content of mitochondrial fractions isolated from this amount of respective tissues differed considerably 
(Table 2), the differences in transaminase activity of the tissues cannot be ascribed to the nitrogen content, because diluted kidney mitochondria show yet a considerable activity as described before ${ }^{11}$.

The distribution of the DPN-linked enzyme is shown in Table 1, B and Fig. 2. The enzyme was fairly active in kidney mitochondria, but the amount of $\mathrm{TA}_{4}$ produced and the ratio $\mathrm{TA}_{4} / \mathrm{T}_{4}$ were much less than those in the case of $\mathrm{T}_{4^{-}}$ transaminase described above. All tissues except for the kidney showed much less activity.

The results shown in Table 1, C and FIG. 3 indicate the following. FMN caused no marked accumulation of $\mathrm{TA}_{4}$ in all cases of tissues. But, unexpectedly, FMN resulted in a significant deiodination of $\mathrm{T}_{4}$ when kidney and liver mitochondria were employed as enzyme sources. The liberation of inorganic iodide and the diminution of $T_{4}$ were conspicuous. At the same time, a significant amount of radioactivity appeared at the filter paper origin, indicating that the radioactive iodide released from $\mathrm{I}^{131}-\mathrm{T}_{4}$ is bound by mitochondrial protein. In the case of a control, in which $\mathrm{T}_{4}$ was incubated only with FMN, deiodination was not apparent. With mitochondria of the heart, skeletal muscle and brain, no marked deiodination took place.

\section{DISCUSSION}

The results obtained above show the activity of three different enzymes connected with respective cofactors, because neither mitochondria from various tissues nor each enzyme cofactor alone yielded any appreciable amount of $\mathrm{TA}_{4}$ and iodide.

Two deaminative enzymes, the transaminase and DPN-linked enzyme, were especially active in kidney mitochondria, and much less active in mitochondria of all the other tissues, the liver, heart, skeletal muscle and brain. AlbRight et al. ${ }^{1)}$ reported a similar distribution of the DPN-linked enzyme extracted from mitochondria. The DPN-linked enzyme of the kidney was far less active than the kidney $T_{4}$-transaminase in deaminating $T_{4}$, as reported before ${ }^{11)}$.

Though the attempt to detect L-amino acid oxidase was unsuccessful, the experiment made clear that there is present in the kidney and liver a potent mitochondrial deiodinase which is linked with FMN. The liver enzyme appeared to be more active. Whether the L-amino acid oxidase acting upon $\mathrm{T}_{4}$ is actually absent in these tissues or the enzyme activity is only undetectable on account of the rapid deiodination of both $\mathrm{T}_{4}$ and $\mathrm{TA}_{4}$, is unknown under the present experimental conditions. The deiodinase was only slightly active in the cases of mitochondria of the heart, skeletal muscle and brain. FMN alone did not appear to cause any notable deiodination. These facts indicate that the deiodination is caused enzymatically. 
The deiodination of thyroid hormones has been investigated by many workers both in vivo and in vitro employing tissue slices; earlier work in this field has been reviewed recently ${ }^{3,4,10)}$. However, up to the present time only a few reports concerning deiodinase of thyroid hormones have appeared and, moreover, there is no agreement in these reports. In the liver, the enzyme was found mainly within the mitochondrial fraction ${ }^{12)}$. The enzyme activity in the skeletal muscle ${ }^{5}$ and brain $^{7)}$ was also studied and it was observed that the enzyme was chiefly located in the soluble cytoplasmic fraction ${ }^{6}$. All these experiments were carried out without adding any enzyme cofactors to the tissue preparations.

The FMN-linked mitochondrial deiodinase described here is interesting because it appears very potent and this type of enzyme has apparently never been demonstrated. More detailed investigation is now in progress and will be reported in the near future.

The fact demonstrated in the present study, that $T_{4}$ is mainly deaminated by kidney mitochondria and mainly deiodinated by liver mitochondria, is in exact accordance with the well-known fact that thyroid hormones are metabolized most actively' in these two organs in vivo.

\section{SUMMARY}

Employing mitochondria of various rat tissues as enzyme sources, and pyridoxal phosphate, DPN and FMN as the coenzymes, a study was made of the distribution of three types of enzymes among the kidney, liver, heart, skeletal muscle and brain. These enzymes are transaminase, DPN-linked deaminase and FMN-linked deiodinase acting respectively upon thyroxine.

The former two deaminases were found to be the most active in the kidney, and of these two the transaminase was far more active than the DPN-linked enzyme.

The FMN-linked deiodinase, which appears to be a new type of enzyme of mitochondrial origin, was the most active in the liver.

The specific feature of such distribution is in accord with the fact that thyroid hormones are deaminated mainly in the kidney and deiodinated in the liver in vivo.

This work was supported in part by the Grant in Aid for Scientific Research-Institutional Research-from the Ministry of Education to which the authors' thanks are due.

\section{REFERENCES}

1) Albright, E. C., Tomita, K. AND LARson, F. C. In vitro metabolism of triiodothyronine. Endocrinology 64 : 208-214, 1959.

2) Nakano, M., Danowski, T. S. AND UTSUmi, A. Metabolism of monoiodotyrosine, diiodotyrosine, triiodothyronine and thyroxine by L-amino acid oxidase. Endocrinology 65 : 242-255, 1959.

3) Pitt-Rivers, R. And Tata, J. R. The Thyroid Hormones. New York, London, Paris, Los Angeles: Pergamon Press, 1959. 
4) Roche, J. ANd Michel, R. Thyroid hormones and iodine metabolism. Ann. Rev. Biochem. 23 : 481-500, 1954.

5) TAtA, J. R. Metabolism of 1-thyroxine and 1-3:5:3'-triiodothyronine by homogenates of rat skeletal muscle. Proc. Soc. Exper. Biol. Med. 95: 362-364, 1957.

6) TATA, J. R. Enzymatic deiodination of 1-thyroxine and 3:5:3'-triiodo-1-thyronine. Intracellular localization of "deiodinase" in rat brain and skeletal muscle. Biochim. Biophys. Acta. 28 : 95-99, 1958.

7) Tata, J. R., Rall, J. E. AND Rawson, R. W. Metabolism of 1-thyroxine and 1-3: 5: 3'-triiodothyronine by brain tissue preparations. Endocrinology 60:83-98, 1957.

8) Tomita, K., Lardy, H. A., Larson, F. C. ANd Albright, E. C. Enzymatic conversion of thyroxine to tetraiodothyroacetic acid. J. Biol. Chem. 224: 387-397, 1957.

9) Yамамото, K. Evidence for the presence of thyroxine- $\alpha$-ketoglutaric transaminase in rat kidney homogenate. Jap. J. Physiol. 9: 394-400, 1959.

10) Yамамото, K. Biosynthesis and metabolism of thyroid hormones. Seibutsukagaku Saikin no Shimpo 5: 114-140, 1959. (In Japanese).

11) Yamamoto, K., Ishikawa, I. and Shimizu, S. Metabolism of L-thyroxine due to transamination by rat kidney mitochondria. Jap. J. Physiol. (In press).

12) Yamazaki, E. AND Slingerland, D. W. The in vitro metabolism of thyroxine, triiodothyronine and their acetic and propionic acid analogues. Endocrinology 64: 126135, 1959. 